\title{
ПРОЦЕССЫ ГЛОБАЛИЗАЦИИ
}

\section{СЕМЬ СЛАБОСТЕЙ АМЕРИКИ И ДОНАЛЬД ТРАМП}

\author{
Гринин Л. Е.
}

Борьба все большей части мирового сообщества с растущим эгоизмом Соединенных Штатов, не желающих признавать общие интересы, уже длительное время составляет главную интригу современного глобального противоречия. В настоящий момент, после прихода к власти Дональда Трампа, это стало особенно очевидным, так как фронт противоречий расширился за счет игнорирования американцами интересов своих союзников. "Сделать Америку снова великой» - этот лозунг Трампа откровенно говорит о потере прежнего уровня лидерства и о том, что ситуация в мире будет обостряться. В этой связи важно увидеть, какова материальная база могущества современной Америки, позволяет ли она «сделать Америку снова великой» или нет. В статье анализируется семь (реальных и потенциальных) слабостей США, часть из которых, однако, в настоящее время как раз поддерживает их могущество. Но рано или поздно эти слабости станут причиной глубокого кризиса и не позволят Соединенным Штатам сохранить свое лидирующее положение.

Ключевые слова: современное глобальное противоречие, Дональд Трамп, эгоизм США, слабости США, дефицит торгового баланса, дефиизит бюджета, государственный долг, доллар, небелое население США, слабость политической системь США, кризис системы здравоохранения, торговые тарифы.

Over a long period of time the main intrigue within the current global contradiction has been the resistance of most part of the world community to the growing egoism of the USA who are not willing to take into account common interests. At present, after Donald Trump's coming to power this has become even more evident after the frontline of the contradictions has expanded since the USA continues to ignore the aliens' interests. "Make America Great Again" this Trump's slogan directly evidences the loss of the former leadership and that the situation in the world is going to heat up. In this respect it is important to consider the material basis of modern America's power and whether it will allow "making America great again" or not. The article analyzes seven (real and potential) weakness of the USA, yet, it is just some of them that currently support its power. But sooner or later these weaknesses will bring the USA to a deep crisis and will not allow preserving its leading position.

* Исследование выполнено при поддержке Российского фонда фундаментальных исследований (проект № 17-06-00464).

${ }^{* *}$ Гринин Леонид Ефимович - д. ф. н., в. н. с. Института востоковедения РАН, зам. руководителя Евро-азиатского Центра мегаистории и системного прогнозирования.

Век глобализации 2/2018 28-45

DOI: $10.30884 / v g l o b / 2018.02 .03$ 
Keywords: modern global contradiction, Donald Trump, American egoism, the USA's weaknesses, the deficit of the trade balance, fiscal deficit, national debt, dollar, people of color, weakness of the American political system, crisis of the health care system, commercial tariffs.

\section{Введение. Обострение основного противоречия современной эпохи}

Вне всякого сомнения, судьба мира во многом зависит от того, как будут развиваться США, какую политику они изберут, какие повороты встретятся на этом пути. В свое время мы писали, что борьба все большей части мирового сообщества с растущим эгоизмом Соединенных Штатов, не желающих признавать общие интересы, будет составлять главную интригу современного глобального противоречия [Гринин 2005: 17; 2015: 13]. В настоящий момент, после прихода к власти Дональда Трампа, это стало особенно очевидным, так как фронт противоречий расширился за счет игнорирования американцами интересов своих союзников.

Говоря об интересах США, нужно иметь в виду, что в последние три десятилетия они неоднократно трансформировались в зависимости от того, какая часть американской элиты, групп давления и так называемого глубинного государства оказывалась в тот или иной момент наиболее активной и влиятельной. Можно сказать, что именно расклад политических сил, внутриполитическая борьба и ее цели во многом определяют важные направления внешней политики страны. Более того, внешняя политика чрезмерно подчинена внутренней, а внешнеполитические акции нередко становятся результирующей внутриполитической борьбы. Так, усиление конфронтации с Россией определяется прежде всего логикой борьбы с Трампом его противников. Между тем с точки зрения долгосрочных интересов США столь сильное обострение отношений с Россией Америке невыгодно, поскольку толкает РФ на формирование блоков с Китаем, Ираном и другими странами (США выгоднее разделять своих противников, не давать им блокироваться). Сложно сказать, насколько Д. Трамп это понимает: в любом случае его попытки наладить отношения с Россией были пресечены, поскольку борьба за власть внутри страны диктует ему стратегию конфронтации. Еще менее разумно обострять отношения сразу со многими странами, как делает Трамп. Но и для него главное - предвыборные обязательства и надежда, что, исполнив их, он переизберется на второй срок. А как это повлияет на будущее Америки, нынешний президент не понимает.

Мы, как и многие другие, неоднократно указывали, что США все заметнее теряют свои лидерские функции [см., например: Валлерстайн 2001; Капхен 2004; Тодд 2004; Грей 2008; Мир... 2009; Закария 2009; Гринин 2009; 2015; 2016а; $2016 б]^{1}$. Мы также отмечали, что в результате этого ослабления в последние годы усиливается «беспорядок» в мире, причем особенно заметный вклад в него вносят действия США [Гринин 2015: 14]. С приходом Трампа к власти и из-за его стремления изменить многие устоявшиеся отношения «беспорядок» еще больше усилился. Это свидетельствует об усилении указанного противоречия.

«Сделать Америку снова великой» - этот лозунг Трампа откровенно говорит о потере прежнего уровня лидерства и о том, что ситуация в мире будет обостряться. В этой связи важно увидеть, какова материальная база могущества современной Америки, позволяет ли она «сделать Америку снова великой» или нет. Настоящая статья посвящена анализу данной проблемы.

\footnotetext{
${ }^{1}$ Более полный список литературы см.: Гринин 2015; $2016 \mathrm{a} ; 20166$.
} 


\section{Слабости Америки: предварительный обзор}

Можно говорить о целом ряде потенциальных слабостей США, часть из которых, однако, в настоящее время как раз поддерживает их могущество. Но рано или поздно эти слабости станут причиной глубокого кризиса и не позволят Соединенным Штатам сохранить влияние.

Условно мы сформулировали эти слабости в семи пунктах, хотя их может быть и больше, и меньше.

1. Огромный и хронический дефицит внешней торговли (в целом счета платежного баланса), который имеет тенденцию к росту.

2. Огромный и хронический дефицит бюджета, который к тому же растет. Существенно снизить и тем более ликвидировать его представляется малореальной задачей.

3. Огромный государственный долг, размер которого постоянно увеличивается; общая закредитованность бизнеса и населения.

4. Особая роль доллара и огромная зависимость от этого американской экономики и внешней политики. Ослабление роли доллара и доверия к нему могут привести к колоссальному и системному кризису в США.

5. Особенности системы здравоохранения. Непомерно высокие цены на медицинские услуги и лекарства подрывают бюджет, являются источником роста госдолга (особенно в условиях старения населения).

6. Уменьшение доли белого населения. Эта и другие социально-демографические тенденции могут привести к ослаблению единства нациии и усилению внутренних конфликтов.

7. Слабость политической системы в условиях глобализации и необходимости удерживать лидерство. Американская политическая система в современный период недостаточно подходит для глобальных внешнеполитических задач, связанных с удержанием американской гегемонии.

В следующем разделе мы подробно проанализируем эти слабости. Вновь подчеркнем, что некоторые моменты в настоящее время являются сильными сторонами США, их внешнеполитическим и геополитическим оружием, но потенциально они несут угрозу всей системе. Такова диалектика: сила переходит в слабость и наоборот, а масштабы проявления этих слабостей с учетом масштабов американской экономики - огромны. Также важно понимать, что эти проблемы появились не вчера: истоки одних прослеживаются начиная с 1960-1970-х гг., других - даже ранее.

\section{Слабости Америки: анализ}

1. Постоянный дефицит внешней торговли. Длительное время после Второй мировой войны экспорт США превышал импорт. Но война во Вьетнаме, отказ от привязки доллара к золоту в результате валютного кризиса 1971-1973 гг., взрывной рост цен на нефть и подъем экономик других стран изменили ситуацию. С конца 1970-х гг. импорт начал превышать экспорт, и торговое сальдо стало отрицательным. С этого времени дефицит торгового баланса является хроническим. Он несколько уменьшился в 1990-е гг., но затем снова стал расти. В 1970 1980-е гг. США периодически и не без успеха вынуждали к различным уступкам (открытию рынков, ревальвации валют) Японию, Германию и другие страны, чтобы сократить этот дефицит. Но, несмотря на это, дефицит постоянно рос, особенно увеличившись в связи с заключением экономического соглашения с Мек- 
сикой и Канадой (НАФТА) и ростом Китая. Сегодня он достиг огромной цифры, приближающейся к 600 млрд долларов (точнее, 566 млрд долларов) ${ }^{2}$. Правда, Д. Трамп, объясняя причины введения тарифов, для усиления эффекта говорит о 800 млрд долларов (813 млрд, такая цифра есть и в онлайн-счетчике долга).

Что означает этот дефицит? Ежемесячно американцы получают от своих торговых партнеров (прежде всего Китая, Канады, Мексики, Германии) товаров в среднем на 45-50 млрд долларов больше, чем продают. Именно огромный дефицит торгового баланса (с учетом того, что потребительские товары производятся в странах с низкой заработной платой) является одной из причин низкой инфляции в США. В целом такой дефицит выгоден американцам. Они получают от торговли значительно больше, чем отдают. И все же такая ситуация ослабляет и без того во многом деиндустриализованную экономику США, делая ее все более зависимой от указанного дефицита, все менее конкурентной. Также она местами продолжает способствовать выводу производств за рубеж. Это беспокоит многих в Америке и является причиной экстравагантных действий Трампа в области введения тарифов на импорт и давления на торговых партнеров. С точки зрения же долгосрочных перспектив в случае возникновения недоверия к доллару или государственному долгу США (что более чем реально) обеспечить такой объем импорта в страну будет невозможно. Последствия нетрудно вообразить.

В принципе, сегодня политика Д. Трампа во многом просто повторяет политику Р. Никсона или Р. Рейгана в отношении Японии и Германии, но, если не принимать во внимание саму экстравагантность Трампа, огромное различие состоит в том, что сегодня эта политика уже стала одиозной и архаичной. В самом деле, США десятки лет выступали за свободную торговлю, «продавливая» этот принцип всегда и везде, и вдруг стали резко от него отказываться, демонстрируя свою беспринципность. Главное, что не хочет принимать во внимание Трамп, это то, что сегодня Америка не в состоянии жить по средствам, не в состоянии отказаться от дефицита торгового баланса, от дарового импорта ${ }^{3}$. Действительно, за 33 года (с 1985 г.) накопленный дефицит торгового баланса составил примерно 13 трлн долларов.

Интересно, что при Буше-младшем в 2007 и 2008 гг. дефицит торгового баланса был еще больше (731 млрд долларов в 2007 г. $)^{4}$. Но столь агрессивных попыток ввести импортные пошлины и разорвать договоренности все же не было. Делая скидку на личностные характеристики Трампа, его стремление устраивать из любого решения шоу и стараться работать на публику, тем не менее можно прийти к выводу, что сегодняшние действия США являются показателем нарастающего кризиса.

2. Постоянный и растущий дефицит бюджета. Бюджетный дефицит - еще более серьезная проблема, чем дефицит торгового баланса. Это также не новое явление, он рос в периоды войн, потом сокращался. При У. Дж. Клинтоне даже пару раз наблюдался профицит бюджета. Но в последние 15 лет дефицит бюджета «вырвался на свободу». При этом если в период рецессии 2008-2010 гг. он был

2 Дефицит счета текущих операций, правда, на 100 млрд меньше (466 млрд долларов), но все равно огромен. США получают часть платежей за лицензии, услуги и кредиты от других стран, что несколько уменьшает проблемы дефицита торгового баланса.

3 Существенно, что при нынешнем дефиците трудовых ресурсов американская экономика вряд ли произвела бы товаров на экспорт на 600 млрд долларов.

${ }^{4}$ Дефицит удалось снизить за счет развития сланцевой нефтедобычи и снижения объема импорта нефти. 
морально оправдан, то в удачные годы - уже нет. Размер дефицита колеблется от 500 млрд до 1 трлн долларов в год (а в некоторые годы и больше). При этом в рамках десятилетнего планирования бюджета (принятого не так давно в США) 1 трлн рассматривается уже почти как норма, а фактический размер дефицита все чаще превышает планируемый. В 2017 финансовом году он составил 665 млрд долларов. В 2018 финансовом году вместо ранее планируемых 563 млрд долларов дефицит бюджета составит 804 млрд долларов, а в 2019 финансовом году достигнет почти 1 трлн (981 млрд) долларов вместо ранее ожидавшихся 689 млрд долларов.

Важно отметить, что основные статьи расходов - социальные, которые рассматриваются как защищенные статьи. Это более 60 \% бюджета (последний уже значительно превышает 4 трлн долларов), в первую очередь пенсии (Social security) и здравоохранение (Medicare), соответственно где-то 33 \% и 28 \% бюджета (вместе около 2,5 трлн долларов). Расходы на оборону огромны - при Трампе они стали превышать 700 млрд долларов ${ }^{5}$. Но все же важно понимать, что именно социальные, защищенные расходы (Mandatory spending) - на пенсии по старости и по инвалидности и медицинское обслуживание, которые нельзя сокращать ни при каких условиях, - дают основной дефицит. Именно это делает невозможным его радикальное сокращуение.

Другие значительные статьи - это расходы на образование, инфраструктуру, науку, поддержку сельского хозяйства и т. д. Наконец, расходы на выплаты процентов по государственному долгу составляют сейчас 7-9 \% от всех расходов бюджета. В перспективе они будут увеличиваться в связи с ростом как самого долга, так и процентных ставок. Последние сейчас низки (хотя уже начали расти), что позволяет обслуживать долг без чрезмерного напряжения, но так будет, разумеется, не всегда. Например, по проекту десятилетнего планирования бюджета в 2026 г. расходы на обслуживание госдолга (планируется выплачивать проценты, а тело долга замещать новым долгом) должны будут составить уже не 7 \% от всех расходов бюджета, а 15 \%. Если же ставки подрастут - и того больше. Такие суммы лягут непосильным бременем на страну (по некоторым данным, процентные выплаты уже в 2022 г. вырастут до 16 \% бюджета).

Те тенденции, которые закладывались в перспективное планирование бюджета при Б. Обаме, новый президент и республиканцы пытаются менять. Во-первых, предполагалось постепенное сокращение доли военных расходов в ВВП страны (с 3,3\% ВВП в 2015 г. до 2,3 \% в 2026 г.). Однако первое, что сделал Д. Трамп, резко нарастил эти расходы. И в 2017 г. они поднялись до 3,8 \% от ВВП 6 . Зато некоторые социальные расходы Трамп пытается урезать ${ }^{7}$, особенно он ополчился на программу медицинской помощи, введенную при Обаме - Obamacare (cм. о ней ниже). Однако даже усиленный натиск не смог закрыть данную программу. И это показывает, что радикально сократить социальные статьи в настоящих условиях невозможно. Напротив, так или иначе (в связи со старением населения) они будут расти.

\footnotetext{
${ }^{5}$ Но с учетом бюджета министерства по делам ветеранов (180 млрд), ряда секретных статей и прочего совокупные военные расходы уже значительно превосходят 1 трлн долларов.

${ }^{6}$ Правда, в 1970-е гг. расходы на оборону в США в среднем составляли 7 \%, а в 1980-е - в среднем 5,5 \% ВВП. Но тогда не требовалось столько расходов на социальные нужды.

${ }^{7}$ В частности, на программу талонов на питание для малоимущих (SNAP), которой пользуются десятки миллионов человек [см.: Ричардсон 2018].
} 
Трамп также добивается увеличения расходов на инфраструктурные проекты и провел налоговую реформу. Это может положительно сказаться на экономике, хотя и не даст какого-либо мощного подъема. Но сокращение налогов - это и сокращение доходов. Последние и без того существенно отстают от расходов (от 15 до $25 \%$ и более, или 3-6\% ВВП).

Интересно отметить, что нынешний президент США не борется и не собирается бороться с дефицитом ${ }^{8}$, и тем более, в отличие от введения импортных тарифов или строительства стены на границе с Мексикой, не делает из него политическое шоу. Это еще раз показывает зависимость внешней политики от внутреннего расклада. Ведь сокращение дефицита бюджета - борьба с собственными избирателями, а кому из политиков хочется это делать? Кроме того, изменения в бюджете требуют одобрения Конгресса, чего зачастую бывает невозможно достичь.

Таким образом, постоянный дефииит бюджета стал неотъемлемой чертой жизни современных США. Он позволяет стране жить не по средствам, служит важнейшим социальным амортизатором, давая возможность осуществлять крупнейшие сочиальные программь (пенсионные, медицинские и др.), а также поддерживать важные институты страны. В случае приведения бюджетных расходов в соответствие с доходами сочиальные отночения в обществе резко обострились бы, уровень жизни резко снизился, а важнейшие отрасли экономики (такие как медицина, фармачевтика, сельское хозяйство) оказались бы в кризисе. Сокращение дефицита и тем более отказ от него могли бы случиться при резком увеличении темпов экономического роста (например, 5 \% в год), но для этого в США нет сегодня ни демографических, ни технологических, ни иных ресурсов и потенций. Однако и бесконечным дефицит бюджета быть не может. Можно предполагать, что дефичит бюджета, причем увеличивающийся, станет одной из важнейших причин будущего глубокого кризиса.

3. Огромный государственный долг и общая закредитованность бизнеса и населения. Постоянный дефицит бюджета является причиной роста государственного долга. На федеральном уровне долг составляет уже около 21 трлн долларов. Какую-то часть элиты это пугает, но многих еще нет. Президент Трамп, в частности, не слишком об этом беспокоится. Мало того, принятое решение по снижению налогов только увеличит размер государственного долга. До кризиса 2008 г. отношение долга к ВВП составляло примерно 60 \%. В настоящее время более $105 \%$. На каком уровне проблема долга станет неподъемной, сказать трудно. Но рано или поздно она непременно станет таковой.

Очевидно, что в связи с постоянным дефицитом бюджета долг будет увеличиваться. Потенциально высокая стоимость его обслуживания будет также расти и превратится в существенно более тяжелое бремя. В настоящее время она составляет заметно более 300 млрд долларов в год. Однако ФРС повышает ставки, а значит, и стоимость обслуживания долга может расти. Каждые $0,25 \%$, которые ФРС добавляет к ставке, могут означать, что стоимость обслуживания долга вырастет на 50 млрд долларов в год (то есть на $1,2 \%$ от всего бюджета).

Внешние кредиторы (Китай, Япония и многие другие) держат порядка 30 \% американского долга (гособлигаций, трежерис). Это, с одной стороны, вливает в сумму долга как бы реальную стоимость. Но с другой - в случае каких-то колебаний и сомнений в прочности американской денежной системы внешние кредито-

\footnotetext{
${ }^{8}$ Хотя во время предвыборной кампании Трамп и критиковал дефицит, борьба с последним не была среди его главных предвыборных обещаний.
} 
ры могут попытаться избавиться от этих долгов, что потенциально способно обвалить трежерис и всю финансовую систему. Чем выше долг, тем больше инвесторы и кредиторы рискуют, поэтому любые сомнения в надежности гособлигаций способны вызвать резкий рост их доходности, что осложняет исполнение бюджета и приведет к наращиванию долга.

Именно для того, чтобы не было сомнений в надежности американских гособлигаций, ФРС старается уменьшить размер долга на своих балансах, так как она скупила гособлигаций на 4,5 трлн долларов.

Многие американские финансовые и социальные институты (в том числе пенсионные и социальные фонды) в той или иной степени вложились в государственный долг. И потенциально здесь могут возникнуть большие проблемы. Вопервых, низкие доходности по гособлигациям усложняют возможности повышения пенсий на инфляцию. Уже сейчас немало случаев, когда пенсионные фонды не могут этого делать, в будущем число таких случаев возрастет. Но если доходность облигаций будет высокой, то окончательно «затрещит» бюджет. Во-вторых, в случае дефолта по госдолгу пенсионная система может обвалиться, что приведет к социальной катастрофе.

Старение населения является проблемой не только Соединенных Штатов, но и многих других стран. И во всех из них обостряется проблема обеспечения пенсионного и медицинского финансирования. Но в США есть существенные особенности (см. ниже). Так или иначе старение и болезни старости не позволят значительно уменьшить эти тяготы американского бюджета. Поскольку пенсионеры и пожилые становятся все более значимой частью электората, ни один политик, ни одна партия не смогут не учитывать их требования. В итоге проблемы дефицита бюджета и государственного долга могут обостряться, а государство вынуждено будет как-то решать и проблемы индексации пенсий 9

Долговая нагрузка в США очень существенна не только на федеральном, но и на местном уровне, также высока закредитованность корпораций и жителей. В США создан онлайн-счетчик долга и других экономических параметров. В апреле 2018 г. он показывал общий долг США (включая корпорации и граждан) почти в 70 трлн долларов (в среднем по 213 тыс. долларов на человека или 836 тыс. на одну семью). При этом только процентов по общему долгу набегает 2 трлн 623 млрд долларов, и это составляет 13,4 \% от ВВП (19,9 трлн). В целом одна седьмая часть американского ВВП - это доходы от обслуживания долгов, сектор в значительной мере паразитический. А чем сильнее паразитически-кредитный сектор, тем больше капиталов отвлекается от реального сектора, и в целом экономика начинает ослабевать.

Имеется и большой долг штатов и территорий ${ }^{10}$. Его возможности роста ограничены (так как ограничены и возможности эмиссии в рамках штатов), отсюда периодически возникают кризисы и деградация ряда муниципальных образова-

\footnotetext{
${ }^{9}$ К примеру, Чикаго должен действовать в соответствии с законом штата, который требует, чтобы город отменил увеличение финансирования по пенсионным обязательствам (основная причина недавнего понижения рейтинга города агентством Moody's), но он не может сократить выплаты ушедшим на пенсию. Среди американских городов с высокими затратами на пенсии Moody's выделяет Санта-Фе (Нью-Мексико), у которого чистые пенсионные обязательства в 6 раз больше его операционного дохода; Вирджинию (Миннесота), где это превышение составляет 5,9 раза; Лас-Вегас (Нью-Мексико) с превышением в 5,5 раза; Чикаго с показателем 5,4 раза.

${ }^{10}$ Согласно данным сайта US Government Debts (https://www.usgovernmentdebt.us/compare_state_debt), в начале 2018 г. он составлял более 3,1 трлн долларов, что равняется почти годовым тратам всех штатов.
} 
ний, вынужденных повышать местные налоги. По некоторым данным, имеется свыше 400 городов, состояние финансов которых делает их кандидатами на банкротство [Роджерс 2017]. В 2017 г., в частности, обострился бюджетный кризис в штате Иллинойс (где находится город Чикаго).

Таким образом, проблема роста задолженности как на федеральном, так и на местном уровне, как у фирм, так и у населения, становится все серьезнее. Какихто радикальных способов ее решения не видно. Попьтки решить ее кардинально приведут к краху сочиальной и политической системы, а отказ от ее решения к неизбежным финансовым долговым кризисам и, возможно, дефолтам.

4. Особая роль доллара в поддержании могущества финансово-экономической мощи США. Роль доллара подчеркивается всеми, и действительно, ее трудно переоценить. Доллар рассматривается как ведущая валюта мира, главное средство расчетов и в большинстве случаев - платежа. Именно доллар позволяет Соединенным Штатам чувствовать себя вольготно в торговых отношениях с партнерами, оказывать помощь в собственной валюте, не держать валютных резервов (которые отвлекают огромные капиталы у многих ЦБ). Но, помимо этого, США, их финансовые агенты и импортеры получают большую выгоду от того, что большая часть платежей проходит именно в долларах. Кроме того, они аккумулируют гигантские чужие капиталы, тем самым имея возможность контролировать многие страны, корпорации и людей. Соединенные Штаты также получают огромные выгоды от того, что доллар является средством накопления во многих странах, значительная часть (до 100 млрд долларов в год) накапливается в наличном виде, то есть, по сути, тезаврируется. Также стоит упомянуть, что ряд стран привязывают свои валюты к стоимости доллара. Словом, без особого положения доллара американская финансовая система, рынок акций и прочее чувствовали бы себя существенно хуже, а их объемы были бы меньше. Сейчас же США живут как рантье во многом за счет особого положения доллара в мировой валютной системе. Большие доходы от зарубежных активов мало способствуют экономической активности внутри страны и росту ВВП.

Важный момент - отношение доллара по стоимости к другим валютам. С точки зрения экспортеров (а также и удобства выплаты госдолга) выгоднее иметь более дешевый доллар. Но для привлечения капиталов (в том числе иностранных) в госдолг и на биржи желателен, наоборот, дорогой доллар. Таким образом, существует противоречие между производительным (который сегодня в меньшем почете, чем раньше) и финансовым капиталом. Поскольку доллар принимается без ограничений, его стоимость регулируется не размером дефицита платежного баланса (как в странах с другими валютами), а спросом на него как на средство платежа, резервов и накоплений ${ }^{11}$. При этом США искусственно и силой поддерживают такой спрос на доллар (наиболее известный пример - обязательство продавать нефть Ближнего Востока и из других регионов только за доллары). Но и валютные резервы многих стран в основной своей массе хранятся в долларах, при этом физически также во многих банках США. Существуют и манипуляции с ценами на золото, чтобы контролировать стоимость доллара.

В связи со сказанным можно подчеркнуть следующее важное изменение. Идет своего рода «перетягивание каната» между долларом как национальной

${ }^{11}$ С 1973 г. рассчитывается индекс отношения доллара к шести другим валютам мира, включая швейцарский франк (индекс USDX), который имеет циклы изменений, иногда поднимаясь выше 100 \%, иногда опускаясь значительно ниже 90 \%. В 2017 г. произошло самое резкое падение индекса с 2003 г. (в предыдущие годы индекс рос), почти на 10 пунктов, и оно продолжалось в первые месяцы 2018 г. 
валютой, которая должна подчиняться внутреннему законодательству, и долларом как мировой валютой. Для того чтобы доллар оставался незыблемой мировой валютой, нужно, чтобы он все сильнее растекался по миру, заменяя внутренние валюты стран. Но в связи с проблемами указанных дефицитов государственных финансов Соединенные Штаты теперь взяли курс на репатриацию капиталов. С этим связаны описанные попытки вернуть прибыль американских ТНК в свою страну, а также «прижать» зарубежные офшоры (при оставлении таковых внутри страны) и оказывать давление на банки других стран в отношении вкладов американских граждан. Этим объясняются и попытки повысить учетные ставки и индекс доллара, что будет привлекать в Америку капиталы из-за рубежа. И такая политика притягивания доллара в США в итоге будет ослаблять его как мировую валюту.

Но, так или иначе, доллар давал, дает и в течение какого-то времени будет давать огромные преимущества Соединенным Штатам, а также вместе с другими преимуществами позволяет им ограничивать финансовые возможности многих развивающихся стран и стран полупериферии в отношении эмиссии валют последних, заставляя их накапливать доллары для такой эмиссии.

Однако финансовые диспропорции, рост дефицитов и долга, а также злоупотребление властью рано или поздно должны завершиться серьезным кризисом доверия к доллару и способности США обеспечить его ценность.

5. Особенности системы здравоохранения. По доле здравоохранения в ВВП США занимают первое место в мире. Эта доля составляет более $17 \%$, то есть каждый шестой доллар создается в системе здравоохранения. Население этой страны тратит больше всех денег на медицину, правда, это не означает, что там лучшая в мире система здравоохранения. Ситуация противоречивая. С одной стороны, столь огромные суммы, которые обращаются в этой отрасли, дают стимул для развития медицины и фармакологии, внедрения новых технологий. С другой стороны, стоимость медицинских услуг просто запредельная. Эти услуги большинство населения может оплачивать только с помощью страховых компаний. $\mathrm{B}$ медицинском страховании огромная роль принадлежит государству ${ }^{12}$. Как уже сказано, доля расходов на медицину в федеральном бюджете намного превышает расходы на оборону. Значительна эта доля и в бюджетах штатов и округов. Остальная часть населения приобретает страховки с помощью работодателя, что является одной из форм привязки к нему работников, особенно уже зрелого возраста [Макаров 2017]. Но при этом довольно значительная часть населения (включая молодежь) не желает платить за страховки, тем самым подвергая себя большому риску, поскольку в случае возникновения серьезных проблем эти люди не получают необходимую медицинскую помощь либо получают ее в недостаточных размерах. До начала в 2010 г. реформы Б. Обамы, который ввел обязательное медицинское страхование, таких было более 40 млн. Обама стремился вовлечь многих из этих людей в систему страхования с помощью новой программы (Obamacare) ${ }^{13}$. Число людей без страховки резко уменьшилось. Однако, не-

12 В широких масштабах это началось с президента Л. Джонсона в 1965 г. Программа Medicaid направлена на оказание медицинской помощи малообеспеченным слоям населения, программа Medicare на оказание медпомощи пожилым людям и инвалидам. С учетом увеличения числа пожилых их стоимость для государства постоянно растет.

${ }_{13}$ Она предполагала введение обязательного медицинского страхования граждан, расширение федеральной программы помощи малообеспеченным гражданам Medicaid, а также введение штрафов для граждан за отказ от покупки медстраховки и для крупных работодателей за отказ страховать своих сотрудников. 
смотря на заверения Б. Обамы в том, что реформа приведет к прекращению роста стоимости страховых взносов, наблюдалась диаметрально противоположная ситуация. Страховка оказалась более выгодной пожилым людям, чем молодежи, которая болеет меньше; она также тяжким бременем легла на плечи корпораций. С приходом Д. Трампа начались атаки на эту дорогостоящую для государства систему (так как государству приходится доплачивать за страховки), попытки создать менее дорогостоящую систему. Пока это не удалось.

Несмотря на все перипетии, вполне очевидно, что американское государство не в состоянии урегулировать проблему обеспечения стареющего населения медицинскими услугами. Напротив, она будет только нарастать. В самом деле, какие варианты здесь имеются? Если предположить, что государство заморозит расходы на здравоохранение, это неизбежно приведет к росту смертности населения. В США и так уже два или три года отсутствует увеличение ожидаемой продолжительности жизни, она даже несколько снизилась. Наблюдается рост смертности среди отдельных групп населения. Вряд ли такая тенденция может продолжаться без нарастания социально-политических проблем, учитывая, что пожилые избиратели составляют большую и, главное, растущую долю электората. Но и существенно увеличивать расходы государства на медицинское обслуживание населения становится все сложнее.

Таким образом, США попали в этом случае в очень серьезную ловушку. Их политическая система будет все заметнее зависеть от пожилого электората и его требований в отношении расходов на здравоохранение, а это наряду с другими социальными расходами будет усугублять проблемы бюджета, государственного долга и налогов.

Остается еще возможность начать регулировать цены на медицинские услуги, чтобы снизить финансовую нагрузку. Но это было бы очень сложно, потребовалось бы изменить всю систему организации здравоохранения, которая жестко нацелена на получение прибыли. По-видимому, в условиях роста числа пенсионеров и пожилых людей эти проблемы будут накапливаться, не получая радикального решения.

6. Уменьшение доли белого населения и другие негативные социальнодемографические тенденции. Речь пойдет о постепенно усиливающемся расколе населения США на стареющее белое население, пока составляющее большинство, и молодое, но иного расово-этнического состава; а также об усиливающемся разделении штатов на политико-демографические группы. Все это влияет и в дальнейшем будет еще больше влиять на политическую ситуацию.

Соединенные Штаты справедливо называют «плавильным котлом», в котором разные нации и национальности, этнические и культурные группы сплавлялись в единую нацию. Однако в последние пятьдесят лет ситуация в этом плане стала меняться. За эти полвека число иммигрантов по сравнению с предыдущим полустолетием, пожалуй, даже возросло (что связано и с падением рождаемости в США, особенно среди белого населения). Во-первых, основное их число стало прибывать из латиноамериканских и азиатских стран, а не из стран с белым населением, как ранее. Во-вторых, в связи с ростом социальных гарантий, льготами в отношении членов семей иммигрантов вместе с молодыми и работоспособными мигрантами приехало много иждивенцев старшего поколения. В-третьих, огромное количество мексиканских мигрантов предпочитало селиться в южных штатах, где и ранее было немало испаноговорящих людей. В-четвертых, нехватка рабочей силы привела в страну многие миллионы нелегальных (прежде всего мексикан- 
ских) мигрантов в эти же штаты. Сегодня они составляют огромную политическую проблему, раскалывающую партии, усиливающую противостояние между центральной властью и штатами и т. п. Добавьте к этому еще и то, что иммиграция использовалась как решение политических задач (и смягчение военно-политических неудач на Кубе, во Вьетнаме и т. д. ${ }^{14}$ ). В результате огромные общины кубинцев, вьетнамцев, пуэрториканцев и представителей других этносов расселились в США, анклавность расселения различных групп мигрантов значимо усилилась. В свою очередь, белое население (в целом более образованное, культурное и богатое) также стремится к сегрегации, предпочитая создавать районы, населенные только белыми. В итоге межрасовое смешение идет слабее процесса расово-этнической сегрегации. И в целом население становится в этническом плане более пестрым, что может увеличить нагрузку на целый ряд правительственных программ - от медицинского страхования пенсионеров до образования.

Но и помимо этого возникают очень серьезные проблемы. Белое население в США (также весьма неоднородное по своему этническому составу) по-прежнему составляет большинство. Однако доли латиноамериканцев (выходцы из Мексики, других стран Латинской Америки и Пуэрто-Рико) и азиатов растут. Но главное, что в связи со старением белого населения и падением рождаемости в этом сегменте в настоящее время среди родившихся детей представителей белой расы уже меньше половины. Эта тенденция продолжается уже около десяти лет, поэтому и в младших классах школ небелые дети также составляют большинство. Разумеется, не слишком значимое, но, так или иначе, тенденция нарастает, и через десять лет небелая часть будет составлять большинство и среди молодежи. А уже их дети, скорее всего, станут явным большинством ${ }^{15}$. Доля небелых (с учетом миллиона иностранных, в основном небелой расы) студентов в вузах США также быстро растет, особенно благодаря специальным программам (правда, качество подготовки американских студентов из-за этого снижается).

«Голос Америки» опубликовал очень показательные цифры. Так, за год (период с 2015 по 2016 г.) белое население увеличилось всего на 5 тыс. человек (то есть практически не возросло), так и не достигнув 200 млн человек (198 млн), зато испаноязычное население увеличилось на 2 \% (то есть на 1 млн 127 тыс. человек) - до 57,5 млн. А азиатская диаспора выросла на 3 \% (более чем на 600 тыс. человек), достигая в настоящий момент примерно 22 млн человек. Все это усугубляется целым букетом других проблем. Неравномерность расселения способствовала тому, что появились штаты, где небелое население составляет очень значительную часть или даже большинство. При этом среди небелого населения явно лидирует латиноамериканское (в том числе в таких крупнейших штатах, как Калифорния и Техас). В итоге наблюдаются падение уровня усвоения английского языка и культуры и фактическое двуязычие. Растет число семей, в которых не говорят по-английски, что, естественно, затрудняет усвоение этого языка детьми ${ }^{16}$. Отсюда размывание типично американской культуры, которая была основой процветания США.

${ }^{14}$ США открывали возможность противникам коммунистических режимов в этих странах в упрощенном порядке уезжать в Америку.

15 Разумеется, следует принимать во внимание имеющуюся тенденцию сокращения рождаемости у представителей небелых рас. Но скорее всего, несмотря на это, рождаемость у них все же достаточно долгое время будет выше, чем у белых.

16 По словам аналитиков центра, из-за притока иммигрантов многократно увеличилось количество школьников, не знающих английского языка, и это затрудняет преподавание в школах. По данным на 
Одновременно наблюдается и неблагополучное положение черного/цветного населения. Его численность растет быстрее белого населения: так, за указанный период она увеличилась на $1,2 \%$ (примерно на 464 тыс. человек) и в настоящий момент едва не достигает 50 млн человек. Однако численность чернокожего населения растет существенно медленнее испаноязычного и азиатского. При этом оно наиболее зависимо от помощи государства и представляет собой наиболее «бунташный» элемент американской нации, имеющий также наибольший процент правонарушителей. Кроме того, существующее неблагополучное положение чернокожей/цветной семьи, где две трети детей рождаются вне брака (в том числе потому, что выгоднее быть матерью-одиночкой и получать от государства пособие на детей), будет способствовать воспроизведению этих проблем и в новых поколениях.

При этом в плане образования и культуры данная часть населения значительно отстает. Наиболее высок образовательный уровень у азиатского населения (в ряде отношений он выше, чем у белого). С одной стороны, оно достаточно конформистское, но с другой - его исходная культура во многом принципиально отличается от протестантской. Поэтому рост численности азиатских общин также ведет к размыванию культуры, поскольку возникают анклавы такого населения.

Итак, весь прирост населения в США, по сути, обеспечивают расовые группье и меньшинства (за счет как естественного прироста, так и иммиграции) ${ }^{17}$, а численность белого населения практически не увеличивается.

Отсюда не за горами ситуация, когда страна может разделиться по расововозрастному признаку: белое население будет преимущественно зрелого и пожилого возраста, а испаноязычное, азиатское и прочее - гораздо более молодым. Несложно представить характер будущих социальных конфликтов на этой почве: неясно, насколько данная более молодая группа будет способна обеспечить пенсии и медицинские услуги для белого пожилого населения и насколько она готова будет это сделать.

Следует еще учитывать, что граничащие с Мексикой южные штаты изначально населяли мексиканцы, которые в настоящий момент нередко рассматривают себя как коренных жителей, считая иногда эти штаты чем-то вроде Новой Мексики. Отсюда налицо рост самосознания латиноамериканского и испаноязычного населения, которого насчитывается порядка 60 млн человек (из общего населения почти в 330 млн человек). Как следствие, возрастает ориентация политиков на это население. Пока оно еще чувствует себя недостаточно уверенно, но постепенно эта уверенность крепнет.

Таким образом, американская начия становится не прочнее, а, напротив, более рыхлой, пропориии расово-этнического и языкового состава меняются с каждым годом не в пользу белого населения, впереди поляризация расовых противоречий, которая зримо выразится в возрастной структуре населения. Все это ведет к тому, что воспроизводство населения в плане уровня образования, культуры, владения английским языком, деловой этики и хватки, стремления к экономической независимости, законопослушности, гражданской позиции и прочего происходит в худших условиях. И хотя многие люди из расовых меньшинств

2015 г., доля детей, в семье которых говорят на иностранном языке, составила 23 \% от общего числа учащихся. Для сравнения, в 1990 г. она не превышала 14 \%, а в 1980-м - 9 \%.

17 Число прибывших за год в США на постоянное место жительства достигает 1 млн человек, а в отдельные годы - даже более. Правда, политика Трампа в настоящий момент направлена на затруднение иммиграции. 
стремятся к образованию и карьере, в целом (за частичным исключением азиатской диаспоры) остальные расовые меньшинства не способны заменить в полной мере выбывающие (в связи со старостью) когорты специалистов и бизнесменов. А именно люди определенного склада и мировоззрения и составляли главный капитал Америки в течение прошедших столетий. Здесь еще стоит иметь в виду особенности американской образовательной системы. Она не подчиняется одному центру, в США нет министерства образования. Образованием управляют на местном уровне. Это имеет и плюсы, и минусы. Поскольку школы содержатся на местные налоги, то чем беднее и ниже по культуре районы (а в целом белые сеттльменты имеют более высокий уровень доходов, чем небелые), тем ниже уровень образования. Этот порочный круг разорвать очень непросто. В итоге он усилит естественную сегрегацию населения по расовому признаку, противоречия между штатами (и внутри штатов), где преобладает белое и небелое население, также и в связи с тем, что численность населения одних штатов будет расти, а других - уменьшаться.

7. Слабость политической системы в условиях глобализации. Политическая система США создавалась для управления не слишком централизованной федерацией достаточно автономных штатов. При этом не предполагалось, что страна будет вести экспансионистскую внешнюю политику. Изоляционизм действительно был ведущей линией внешней политики США на протяжении длительного времени. И по сей день большинство населения традиционно мало интересуется внешними событиями, а средства коммуникации посвящают им относительно немного места.

До Гражданской войны страна не обладала сколько-нибудь серьезной армией. Рост экономического могущества США, вовлечение их в мировые войны, необходимость управлять побежденными и оккупированными странами и противостоять $\mathrm{CCCP}$, а также развитие налоговой системы и рост социальных программ - все это и многое другое вызвало к жизни невиданный по мощи ВПК и резко усилило роль и могущество государственной машины. Соединенные Штаты Америки фактически стали гигантской мировой империей, имеющей сотни военных баз по всему миру, в той или иной степени контролирующей десятки стран и ведущие мировые организации, держащей на «крючке» многие тысячи политиков и активистов, журналистов, бизнесменов и т. д. Однако их политическая система не перестроилась в достаточной степени (да и не могла перестроиться) под эти задачи. Не случайно Дж. Фридман в своей книге «Следующие 10 лет», посвященной прогнозу на 2011-2021 гг., назвал Америку «нечаянно возникшей империей» [Фридман 2010: гл. 1] и предсказал, что в это десятилетие США столкнутся с последствиями своего превращения в империю. Хотя многие предсказания этого политического аналитика не сбываются, однако проблемы он ставит глубокие и неординарные. Суть их в том, что Соединенные Штаты по факту являются империей, и управление этой империей - важнейшая задача, стоящая перед этой страной. Но их политическое устройство архаично и не предназначено для того, чтобы рационально управлять миром. В итоге «стремление США к мировому господству подрывает республику» [Там же: 10]. Фридман ставит важные вопросы: можно ли управление империей совместить с требованиями республики? Сможет ли сохраниться республика в условиях имперской ситуации? Сможет ли республика пережить ошибки управления империей? [Там же: 10-11].

Отсюда мы можем сделать вывод, что Республика и демократия, лежащие в основе политической системы США, противоречат их имперской позиции. И это 
противоречие не поверхностно, а системно, Республика и демократические иенности будут все сильнее вступать в конфронтаиию с Империей, а поскольку ни от Республики, ни от Империи Соединенные Штаты отказаться не смогут, все это будет очень сильно и неожиданно влиять на политические процессы в США и болезненно отражаться в мире.

С одной стороны, во внутренней политике президент «упирается» в созданную 250 лет назад систему сдержек и противовесов и конституцию, которую практически невозможно изменить, а также в особенности партийной системы. Но зато внешняя политика большей частью является прерогативой института президента. И, кроме этого института, почти нет законодательно оформленных правил, которые регулировали бы внешнюю политику. А ведь США претендуют на почти абсолютную власть в мире. В итоге управление Империей определяется пониманием президента, влиянием ВПК и лоббистов, а также различных секретных служб вроде ЦРУ и АНБ и, как уже сказано, в огромной степени зависит от внутреннего расклада политических сил на данный момент. Вот и получается, что с каждым новым президентом внешняя политика может меняться и, как показал пример Д. Трампа, меняться круто и даже непредсказуемо, а договоренности с другими странами - отбрасываться за ненадобностью. Дж. Фридман, который призывал усилить внешнее могущество США, тем не менее признавал, что в нынешней ситуации президент должен управлять американской империей так, чтобы скрывать от населения реальные направления американской гегемонии. Именно так поступает президент Трамп, оправдывая все свои внешнеполитические действия попытками решить внутренние проблемы и задачи. А в итоге хаос и напряженность в мировой системе нарастают.

Таким образом, налицо диспропориии между имперскими амбищиями и обязательствами, с одной стороны, и уязвимостью способности выполнять эти обязательства вследствие особенностей политической системы и американской демократии - с другой.

Иными словами, гигантская власть США над миром и объективно вытекающая отсюда ответственность за мировой порядок вступает в жесткое противоречие с архаичной политической системой и фактической безответственностью политического американского истеблишмента, не просчитывающего последствия внешнеполитического курса, который опирается прежде всего на действия разведок и силу (политику, которую давно окрестили «политикой большой дубинки»), но не годится для рационального управления Империей.

Фридман полагал, что новые президенты усилят внешнеполитический аспект, но вышло как раз наоборот - приход к власти Трампа этот аспект ослабил ${ }^{18}$. С одной стороны, новый президент стал рассматривать союзников, партнеров, контрагентов США как вассалов, которые должны только платить, ничего не требовать и знать свое место. С другой - он резко принизил влияние даже тех мировых организаций, которые в известной мере институционально осуществляли контроль над многими странами, как то: ВТО, МВФ, частично ООН, а также сократил приток американской помощи НПО и государствам. Такой поворот очевидно наносит сильный удар по выстроенной системе глобального управления.

\footnotetext{
${ }^{18}$ Создается впечатление, что Б. Обама пользовался рядом идей, которые излагает Дж. Фридман, в частности, в отношении ослабления связей с Израилем и налаживания диалога с Ираном. Однако Д. Трамп перечеркнул многое из внешней политики Обамы.
} 
США очень часто сравнивают с Римской империей, но, видимо, корректнее говорить о сравнении с Римской республикой. Политическая система последней была создана для городской общины, а по факту она к I в. до н. э. захватила весь западный мир. Возникло разделение на архаичную республику и покоренную римлянами территорию, по факту - Империю. В итоге римский сенат оказался не способен эффективно управлять этой империей, поскольку в самом Риме борьба за власть приняла самые жесткие формы. Начались гражданские войны, которые закончились созданием ранней империи во главе с императором. Современная демократическая система США, где сенаторы ответственны перед своими избирателями и партиями, но не перед народами стран, в дела которых США вмешиваются, так же мало способна эффективно управлять мировой империей, как и Римская республика. Но и трансформироваться в реальную империю во главе с президентом-императором она не способна. Отсюда можно прогнозировать усиление кризиса в политической системе Америки, что будет болезненно и неожиданно отражаться на самых разных странах и мировых процессах. Дело в том, что если главный приз в политической борьбе лежит в рамках внутренней политики США (с учетом архаичности их выборной системы президента), то все внешнеполитические проблемы могут быть подчинены этой борьбе, а все союзнические и иные обязательства могут быть легко отброшены. Последнее, собственно, и подтвердил Д. Трамп, показав, что президент может пожертвовать многими имперскими интересами ради поддержания собственной популярности. Такой поворот, такой уход в изоляционизм может быть полезен политику, но так нельзя управлять империей.

Как сама необычная президентская кампания 2016 г., во время которой политическая машина США дала сбой, позволив прийти к власти человеку со стороны, так и резкие повороты внешней политики Трампа со всей очевидностью показывают, что политическая система и политическая машина США являются наиболее устарелой и уязвимой частью системы. И при этом, как показывает пример того же Трампа, изменить ее крайне сложно.

\section{Как усугубить слабости?}

Bсе описанные характеристики имеют тенденцию к усугублению, причем весьма заметную. В последние годы наблюдается зримый рост дефицита внешнеторгового баланса и бюджета, а также увеличение госдолга. Бурный подъем добычи сланцевых энергоносителей при Обаме уменьшил зависимость США от импорта нефти (что было одной из главных статей импорта). Однако то, что дефицит внешней торговли продолжает расти, свидетельствует о неспособности современной Америки жить по средствам. То же касается роста дефицита бюджета и национального долга. В последние годы президентства Б. Обамы он стал замедляться (оставаясь огромным), но при Д. Трампе эти тенденции вновь усилились. Таким образом, если два-три года назад общий объем «подкормки» США составлял 1 трлн долларов (примерно 500 млрд - дефицит внешней торговли и 500 млрд дефицит бюджета), то сейчас он уже приближается к 1,5 трлн (примерно 600 млрд долларов - дефицит внешней торговли и 800 млрд - дефицит бюджета). Это составляет около $8 \%$ от ВВП. Очень вероятно, что в ближайшие годы он достигнет 2 трлн (до $10 \%$ ВВП). Фактически весь рост американской экономики после 2009 г. обеспечивался этими вливаниями, а также количественными смягчениями и подешевевшим кредитом. 
Столь огромная сумма, требующаяся для сохранения на плаву американской экономики и общества, становится уже непосильной ни для Соединенных Штатов, ни для мира. Ведь эти деньги берутся не просто из воздуха, это долги, которые придется в той или иной форме отдавать будущим поколениям. Довольно долго часть этих экстрадоходов США обеспечивалась ростом развивающихся экономик, которым нужны рынки сбыта. Постоянный активный баланс торговых операций и огромные накопления долларовых резервов были в некотором роде их добровольной данью США. Но теперь Империи стало недостаточно добровольной дани. Она все чаще требует принудительных жертв (например, в виде уплаты торговых тарифов, увеличения военных расходов, идущих на закупку американского вооружения, штрафов, налагаемых на банки и корпорации, конфискаций вкладов и т. п.). А это снижает возможности роста экономик и ведет к обострению отношений в мире. Соединенные Штаты не желают признавать законные интересы своих торговых и иных партнеров и союзников, а также их корпораций, рассматривая все страны как в той или иной мере своих подданных и «данников».

Таким образом, рост потребности американского общества в дополнительных средствах наталкивается на ограничения и сопротивление; все это ведет $к$ попыткам уйти от американской, в том числе долларовой, зависимости. А рост рисков каких-либо санкций или недружественных действий со стороны США может побудить те или иные страны выйти из американских облигаций или, по крайней мере, не увеличивать их число в портфелях, что может повлиять на доверие к ним и в целом к доллару ${ }^{19}$.

Сила американской финансовой системы, как уже было сказано, во многом держится на притоке капиталов, а это напрямую связано с доверием к доллару и ценным бумагам. Именно поэтому ослабление доллара, выгодное экспортерам, может спровоцировать проблемы.

При любом раскладе, однако, рост развивающихся экономик в дальнейшем будет в целом сильнее роста развитых экономик и США, тем более что число таких поднимающихся экономик увеличивается, а население в этих странах растет быстрее, чем в Соединенных Штатах, и оно заметно моложе стареющего американского. А это значит, что ослабление влияния американской экономики на мировую неизбежно. Ситуация в финансовой системе для США более благоприятна, но и с ней, как мы видели, далеко не все в порядке.

Все указанные слабости объективны, сделать с ними что-либо радикальное в плане положительном - трудно. С такими, как изменение расового и этнического состава, по-видимому, даже невозможно. А вот ухудшить ситуацию, усугубить их - вполне возможно. И думается, что Д. Трамп способен усугубить большинство из этих слабостей.

В частности, рост американской экономики в существенной мере связан с постоянным притоком рабочей силы в виде иммигрантов, включая и нелегальных (без которых определенные отрасли, особенно сельское хозяйство и садоводство, вряд ли смогут обойтись). Поэтому любые меры, которые усложняют иммиграцию в США - а именно такие меры активно применяет Трамп, включая активную депортацию нелегалов и попытки отменить для них меры защиты в ряде крупных

${ }^{19}$ Как прекращение количественных смягчений, повышение учетных ставок, так и курс на уменьшение объема трежерис на балансе ФРС связаны именно с тем, что американский регулятор опасается уменьшения доверия к этим бумагам и доллару. Но такой курс сталкивается с ростом дефицитов и долга, с агрессивным внешнеполитическим курсом. 
американских городов (так называемые убежища), - будут негативно влиять и на рост американской экономики (в которой сегодня уже существует дефицит рабочей силы из-за старения населения).

Д. Трамп отказался подписывать соглашение о Транстихоокеанском партнерстве. Но оно формируется без США. Нынешний американский президент пытается подорвать устойчивость НАФТА, отказаться от правил ВТО и т. д. В итоге это значит, что роль США потенциально будет снижаться, а роль других стран - расти.

Трамп начал борьбу с дефицитом внешней торговли. Но, кроме усугубления ситуации, это вряд ли даст что-то серьезное экономике или бюджету США. «Обиженные» страны будут вводить пошлины на американские товары, а компании, которые это затронет, станут либо искать новые рынки сбыта вне США, либо повышать цены ${ }^{20}$. Да, это может заменить часть китайских товаров на американском рынке на вьетнамские, бангладешские, лаосские и др., но не решит проблему дефицита торгового баланса, а в целом создаст дополнительные препятствия для роста экономики.

То же касается дефицита бюджета и роста национального долга, если усилятся попытки их снизить. Сохранить социальные расходы без постоянного роста долга невозможно, их сокращение ведет в потенции к серьезнейшему социальному кризису. Вот почему рост социальных проблем способен только усугубить все слабости, поскольку политическая борьба требует потакать избирателям, а не ужесточать социальную политику. Старение и болезни нельзя игнорировать ни одному политическому деятелю. Недаром социалистические лозунги становятся все популярнее в США. Нужно также учитывать особенности избирательной системы (президента) в Америке, где все голоса в отдельных штатах передаются победителю. В этом случае идет поляризация штатов (в частности, с преобладанием небелого и белого, иммигрантского и коренного населения и т. п.), что способно усугубить процесс дезинтеграции.

$$
* * *
$$

Таким образом, все указанные особенности и проблемы в перспективе будут только обостряться, а в связи со слабопредсказуемой политикой Трампа, которая резко усугубляет противоречия между США и множеством стран, включая их ведущих торгово-экономических партнеров, могут проявиться критически уже в обозримом будущем.

В ближайшие годы почти неизбежен экономический кризис в США, который резко усложнит все проблемы. Но даже без учета возможных экономических кризисов и рецессий в последующие двадцать лет Соединенные Штаты ждут весьма радикальные и в целом негативные изменения. Только новая технологическая революция (в ближайшие 7-10 лет) со стоящими во главе ее США могла бы переломить ситуацию, однако за это время полноценной технологической революции не случится, она произойдет существенно позже и вовсе не обязательно в США [см. подробнее: Гринин Л. Е., Гринин А. Л. 2015]. Поэтому обострение экономических, политических и социальных проблем с большой долей вероятности при-

${ }^{20}$ Компания «Рuma», треть производственных мощностей которой расположена в Китае, планирует, например, делать и то и другое [У Якунь 2018]. Этот же материал лишний раз доказывает, что перенос производств обратно в США выглядит утопией. 
ведет к глубокому и системному кризису в Америке, кризису, который, конечно, заметно отразится на «самочувствии» всего мира, но в итоге ускорит процесс изменения политического и экономического порядка в мире.

\section{Литература}

Валлерстайн И. Анализ мировых систем и ситуация в современном мире. СПб. : Университетская книга, 2001.

Грей Д. Величие Америки рухнуло и раскололось на куски // ИноСМИ. 2008. 1 октября [Электронный ресурс]. URL: http://inosmi.ru/world/20081001/244365.html.

Гринин Л. Е. Глобализация и национальный суверенитет // История и современность. 2005. № 1. С. 6-31.

Гринин Л. Е. Приведет ли глобальный кризис к глобальным изменениям? // Век глобализации. 2009. № 2. С. 117-140.

Гринин Л. Е. Новый мировой порядок и эпоха глобализации. Ст. 1. Американская гегемония: апогей и ослабление. Что дальше? // Век глобализации. 2015. № 2. С. 2-17.

Гринин Л. Е. Мировой порядок, Арабская весна и наступающий период глобальной турбулентности // Системный мониторинг глобальных и региональных рисков: Арабская весна в глобальном контексте / отв. ред. Л. Е. Гринин, А. В. Коротаев, Л. М. Исаев, К. В. Мещерина. Волгоград : Учитель, 2016а. С. 191-239.

Гринин Л. Е. Мировой порядок в прошлом, настоящем и будущем // История и современность. 2016б. № 1. С. 20-63.

Гринин Л. Е., Гринин А. Л. От рубил до нанороботов. Мир на пути к эпохе самоуправляемых систем (история технологий и описание их будущего). М. : Моск. ред. изд-ва «Учитель», 2015.

Закария Ф. Постамериканский мир будущего. М. : Европа, 2009.

Капхен Ч. Закат Америки. Уже скоро. М. : АСТ; Люкс, 2004.

Макаров Б. Здоровье нации: настоящее и будущее американской системы здравоохранения // TACC. 2017. 3 августа [Электронный pecypc]. URL: http://tass.ru/ mezhdunarodnaya-panorama/4459894.

Мир после кризиса. Глобальные тенденции - 2025: меняющийся мир. Доклад Национального разведывательного совета США. М. : Европа, 2009.

Ричардсон Дж. Очередные нападки на продуктовые карточки для малоимущих // ПолиСМИ. 2018. 28 апреля [Электронный ресурс]. URL: http://polismi.ru/politika/ob ratnaya-storona-zemli/2026-ocherednye-napadki-na-produktovye-kartochki-dlya-maloimush chikh.html

Роджерс А. Банкротство штата Иллинойс и его последствия // Новостной Фронт. 2017. 29 июня [Электронный ресурc]. URL: https://news-front.info/2017/06/29/alek sandr-rodzhers-bankrotstvo-shtata-illinojs-i-ego-posledstviya/?utm_referrer $=h t t p s \% 3 a \% 2 f \%$ 2fwww.google.ru\%2f.

Тодд Э. После империи. Рах Americana - начало конца. М. : Международные отношения, 2004.

У Якунь. Рита обдумывает вывод производства из Китая, но не будет переносить его в США // ИноСМИ. 2018. 1 мая [Электронный ресурc]. URL: https://inosmi.ru/ economic/20180501/242121484.html.

Фридман Дж. Следующие 10 лет. М. : Эксмо, 2010. 